'From Innocence to Experience: The Representation of Children in Four Documentary Films' (Stella Bruzzi)

Children in front of the camera in nonfictional situations are fascinating and often unusually affecting. Quite possibly - and legitimately - the adult viewer might assume that children have not yet learnt how to 'perform', an oft-loaded term that carries connotations of inauthenticity and pretence and, in turn, signals the ability to be someone or something other than oneself. Stripped of knowingness, a child's tears or expressions of wonder become affecting because they seem genuine and spontaneous. Although not a documentary example, a children-on-film moment that I (like countless others) have always found profoundly affecting is the puppet show in Truffaut's Les 400 Coups, in which Antoine and his classmate attend a marionette performance of Little Red Riding Hood during their day of playing truant from school. Intercutting between the action on stage and longer and slower observational tracking shots capturing the grimaces and laughter on the young audience members' faces, this sublimely simple sequence encapsulates the beauty of innocence, although it is itself a simulation of sorts a moment of cinema verité seamlessly interwoven into in a semi-autobiographical fictional nouvelle vague film. As a film that is, in essence, about a child's (Antoine's) lost innocence, the ingenuousness of the documentary-sequel children further contrasts with the disingenuous, cynical detachment of Antione and his mate, who sit at the back only half paying attention to the violent tussle between Red Riding Hood and the Wolf, as they talk through the potential logistics of pawning a parent's typewriter. Although we adults would like to think that the spontaneous and uncontrolled facial contortions of Harry, the poster boy for Spellbound, Jeffrey Blitz's 2002 documentary feature about the fiercely competitive kids' spelling bee competition, are exemplary of the child's inherent lack of 
guile, the frisson generated by the child's performance arguably emanates from the realisation that maybe their innocent exterior is a canny façade.

In relation to primarily fiction cinema, British critic Mark Cousins talks, in his introduction to a short season of films on the subject, of the 'long symbiotic relationship between childhood and cinema', dating back he argues to Louis Lumière's 1895 Le Repas de bébé, a 41-second home movie of the director's niece eating breakfast (Cousins). This symbiosis, demonstrated by Truffaut, arguably stems from the centrality of the gaze to the child's negotiation with the world around her/him (the child's voyeurism mimicking and recalling the camera's). It is not uncommon in the movies for the child's look to be literally that of the 'peeping tom': gaining an incomplete image of the adult world as Scout, for instance, does towards the end of Robert Mulligan's adaptation of To Kill a Mockingbird (1962) as she witnesses Bob Ewell's attack on her brother Jem. The child in fictional cinema is frequently a witness (as Cousins observes), and as a result sees his or her innocence compromised by being compelled to observe events going on around them, from the Second World War (Germania Anno Zero; The Search), to adult violence (Witness; A Perfect World), to adult sexual desire (Body Heat; The Piano). Often, the affectiveness of the cinematic child comes from them having been forced to grow up too soon, as in The Florida Project. Marcia Landy identifies the child on film as a complex and resonant signifier when she writes:

the cinematic child and adolescent have functioned variously as signifiers of innocence in a corrupt world, melodramatic images of martyrdom tied to the disintegration or regeneration of society, figures of nostalgia for a lost past, signs of generational warfare in society, and as means of providing a different and distanced perspective on familiar social situations (2000: 234).

Italian cinema, especially of the neorealist era, offers up several notable children: the disillusioned child in Ladri di biciclette; the streetwise child in de Sica's later Sciuscià or Rossellini's Paisà. Another affecting feature of these and other examples is that, as Landy notes, the child is viewed through an implicitly or explicitly adult lens; another 
determining factor in the neorealist or nouvelle vague examples being the proximity of real world troubles. The child's encounter with the truth of our adult world undermines or destroys childish 'innocence' and is affecting by having become a traumatic moment of rupture: the children of the kindertransport, whose stories are told in the 2000 documentary Into the Arms of Strangers; the tragic photograph of the three-year-old Syrian boy washed up on the shores of Turkey. The conjunction of crisis, reality and lost innocence is key to these images' affect, and a similar confluence informs other documentaries such as the Netflix series The Keepers (Ryan White, 2017) or Andrew Jarecki's series The Jinx: The Life and Deaths of Robert Durst (HBO, 2015) in which Durst's murderous violence is linked indirectly to childhood traumas such as allegedly being made to witness, aged 7, his mother's suicide.

As routes to exploring various ways in which the effect of childhood innocence is represented in documentaries and concomitantly how children negotiate their relationship to the documentary camera, this article will focus on four case studies: the relatively ingenuous images of childhood proffered by 'Seven Up!' (Paul Almond, 1964) and Etre et avoir (Nicolas Philibert, 2002), contrasted with the more disingenuous ones in Capturing the Friedmans (Andrew Jarecki, 2003) and Tarnation (Jonathan Caouette, 2003). The effect of the children across these examples is different; whereas the fresh openness of Neil in 'Seven Up!' or Jo-Jo in Etre et avoir is warmly affecting, reminding us cynical adults of the innocence of childhood, the effect of the more desperate, traumatised portraits in Capturing the Friedmans or Tarnation serves instead to remind us of the infinite corruptibility of childhood and the loss associated with the child forced to grow up too quickly. In all these examples the camera is allied to the adult point of view; so, we, as adult viewers, are also forced to acknowledge our responsibility for the images, and indirectly for the betrayal of childhood present in all the films. 
As a prelude to these discussions, I will turn briefly to an earlier example of affecting documentary children in the final reel of John Huston's San Pietro (1945), the middle part of his wartime documentary trilogy, which shows the American army's arrival (at the very end of 1943) into the liberated but virtually destroyed Italian hilltop town of San Pietro Infine, a town that was never rebuilt and now only exists as ruins in the Liri Valley between Rome and Naples. As touched on above, the image of the child is perpetually and inherently ambivalent: the proclamation of as yet uncorrupted innocence or, as Jacqueline Rose observes in a discussion of the eternal child, Peter Pan, the embodiment of innocence 'as a value literally and brutally under assault (Rose 1984: xi) following traumatic discovery of its loss. San Pietro narrativises in its final reel the division between the domains of adulthood and childhood and the traumatic loss of innocence. Until these last ten minutes, San Pietro has been extremely gritty, realistic and adult. Huston and his crew filmed alongside infantrymen and, until the last reel, the documentary's brutal images have been accompanied by Walter Huston's booming, didactic voiceover, describing the advances of the US Army's $143^{\text {rd }}$ regiment through the Liri Valley. The entry of some of the US forces into San Pietro (two battalions continued on towards Rome) marks a moment of significant transition, as the documentary's style alters completely. In the last ten minutes, music replaces Walter Huston's insistent narration; and rather than individual shots being filled with the frantic, dangerous action of combat, each image now focuses on civilians, often children, returning to their ruined lives (many had been living in caves nearby as the battles of liberation raged around them). The images underline starkly divergent generational perspectives on the experience of war: weeping mothers breastfeed their suckling babies; women transport their lives' belongings on their heads - one carries baskets, others a suitcase or a sideboard, and one, with equal poise and purposefulness, balances aloft a small-sized coffin; a man, his face contorted by fresh grief, turns despairingly, accusingly towards the 
impotent camera after unearthing a body (we presume his wife?) in the rubble. This look into the lens is the appeal of last resort. Then the children emerge from hiding, and as they do, they demonstrate an entirely different rapport with the camera. Some run towards it, grin into it, or are stopped in their carefree tracks by it; others point at it. It is an object of novelty and fascination. Children simply walk in front of it, while others run past it. Finally, there's the one little boy, treading thoughtfully up a steep, rubbly path, who eyes the camera with deep suspicion and who stops before he gets to it, as if it is obstructing his way and will not let him pass. This camera that had, for two reels, framed death, here alights on a peculiarly mid- $20^{\text {th }}$ century 'innocence', namely children who have never been filmed before.

Intermittent narration does return, to remind us that living has resumed in San Pietro', exemplified by the village's children who are, we are assured, 'able to forget quickly'. 'Yesterday', (Walter) Huston continues, 'they wept, today there are smiles and even laughter. Tomorrow it will be as if the bad things had never happened'. However, rather like the rest of the film (which was accused by the U.S. Army at the time of being both too graphic and anti-war in its sentiments) San Pietro's final reel is tonally ambiguous: children, the authoritative voiceover informs us, forget the horrors of war, they symbolise regeneration, life and the future; and yet, even as they beam unselfconsciously into the lens, (John) Huston's camera dwells on some of the less comfortable realities of the children's present existence, which we, his spectators, cannot help but project into the future: their wild, matted hair and dirty faces, their ramshackle get-ups of filthy trousers and makeshift belts, threadbare sweaters and grubby socks, crude handmade shirts and the battered adult shoes one child wears as he traipses through a muddy field. These children have a simple and straightforward relationship to the camera, but they also do not yet understand how it is representing them nor what messages - about class, poverty, war - are conveyed through the compelling images of 
them. The sparse use of voiceover for this reel in an otherwise 'Voice of God'-heavy documentary is highly suggestive of a certain adult guilt (or at the very least selfconsciousness) symptomatic of acknowledgement of the grimness of these children's lives. At the same time, San Pietro, in its narration, seeks to disavow the likely hardships still to come, and succumbs to external pressures to give the documentary an implausibly uplifting ending. In this instance, tensions between the adults' and the children's perspectives are silent, eloquent reminders that children find themselves caught up in events that circumscribe and damage their lives forever, but over which they have little or no control. One of the most beautiful moments in Huston's powerful documentary is a close up shot, held for a couple of seconds longer than most, of a dishevelled, carefree girl smiling into the camera, breathing in an excessively heavy manner as if excited as well as self-conscious at this novel scrutiny. This moment is sweet though heavily poignant and carries various inferences: the girl has most likely been surviving in a cave alongside her family to escape the battle over her town; she has hitherto never seen anything as sophisticated as a movie camera and is fascinated by it; she has been singled out, which makes her feel special, wanted. This is the uncomplicated version of the relationship between apparatus and subject, but this is a film about war in which context is all, so the girl's innocence is entirely circumscribed and compromised by the brutality it represses. In San Pietro, the nonfictional camera is palpably authoritative, the tool of the Allied liberators of Italy; in the context of the film's final reel it becomes explicitly adult. The relationship between who is doing the looking and who being looked at becomes an unequal one, although such inequality does not pertain exclusively to the adult—child dynamic but can be discerned in other power relations as a result of differences of class, race or gender, imbalances that all inevitably recall the early psychoanalytic film studies debates around the look, voyeurism and objectification. The divergence between adult and child points of view remains one of the most overt, and in this the child is arguably 
'doubly marginalized'. 'However cute the children are throughout San Pietro's impressionistic final reel, they are nevertheless the vulnerable objects of a sophisticated subjective gaze, not yet equipped with the tools to comprehend the events around them or challenge the ways in which their images are framed. This lack of knowledge is rendered in San Pietro as innocence, in all its pre-Fall complexity, for John Huston has emotively and provocatively juxtaposed the images of these children with the violence of war and loss of life that threatens to consume and corrupt them. If we contrast for a moment the hyperventilating girl's excited look to camera with the distraught man's anguished gaze, a few minutes earlier, into that same lens, then it becomes evident that part of what these final minutes of San Pietro illustrate is that the art of being 'looked at' is something that is learnt, that falls within the realm of adulthood and experience, manifest only once innocence has been lost.

Thinking principally about the torture of Iraqi prisoners in Abu Ghraib, Susan Sontag wrote:

To live is to be photographed, to have a record of one's life, and therefore to go on with one's life oblivious, or claiming to be oblivious, to the camera's nonstop attentions. But to live is also to pose. The act is to share in the community of actions recorded as images (Sontag 2004: 28).

For Sontag this postmodern definition of living as having one's life recorded in images is, within the parameters of this article, allied to adulthood in the sense that it is related to a time when one realises some of the potential connotations of the photograph and the pose. The symbiosis between life and record argued for by Sontag in relation to the photographs taken in Abu Ghraib is central to documentary (or the 'art of record') ${ }^{2}$ more broadly, and echoes Judith Butler's definition of gender as imitative and performative, while also recalling early writings on the gaze in art and cinema. ${ }^{3}$ I would like to propose that we use these ideas, alongside Sontag's belief in life's innate performativity, as tools through which to begin to articulate the collision and friction as opposed to the similarity 
between the child's look and the adult's perspective in documentaries. Children in documentaries (occupying Mulvey's state of 'to-be-looked-at-ness') are usually unaware of the connotations their images carry, even in the most desperate and brutal situations. Vicky Lebeau argues for the self-sufficient resonance of images of children: 'It is often enough, the photographic image of a child - whether still or moving - that comes both to render our hostility and to rend the visual field' (138). Lebeau subsequently lists some of the most iconic, eloquent images of children:

the small boy, wearing a cap and a yellow star, raising his hands at gunpoint, during the Nazis' destruction of the Warsaw ghetto in 1943 ... a young girl, Elizabeth Eckford, surrounded by a white mob, as she walks to school in Little Rock, Arkansas in 1957; a naked young girl, nine-year-old Phan Thi Kim Phuc, fleeing her village in South Vietnam after being doused with napalm ... the photograph of a newborn baby, buried in the rubble of a Beirut suburb ... towards the beginning of 2006 (138).

Abused, distraught, murdered children render so fully the horrors of war because the child's very lack of awareness exists in contradistinction to them. Echoing Sontag's post9/11 imperative 'Let the atrocious images haunt us' (2003: 102), Lebeau goes on to remark that 'such images may well have a unique capacity to haunt us' as 'they haunt the visual iconography of childhood' and function as 'evidence of the destruction of children and childhoods, cultures and communities' (138-9). These_are documentary examples of the image of a child articulating the violation and destruction of childish naivety.

Adulthood and adult performances are far more readily and frequently performative than children's. To return to San Pietro: the resurfacing children lack guile as if they have not yet learnt that identity is imitative. As Butler articulates in Gender Trouble, acts, gestures, and desire produce the effect of an internal core or substance, but produce this on the surface of the body ... Such acts, gestures, enactments, generally construed, are performative in the sense that the essence or identity that they otherwise purport to express are fabrications manufactured and sustained through corporeal signs and other discursive means (Butler 1990: 136). 
Nor do the children in Huston's documentary think that to 'live is to pose'. They are in dialogue with the camera, not so much aware, as yet, of how it is making them look. In the throes of a different war, the terrified North Vietnamese girl fleeing her napalmed village is confronted with the extreme cruelties of the adult world, but she is likewise unaware (until later) of her image's broader, transformative connotations. Kim Phuc at first (in 1972) hated the photograph of her and 'struggled' with the publicity that surrounded it. Eventually, she 'came to realise', as two journalists phrased it, 'that if her pain and terror had not been captured on film that day, the bombing - like so many other wartime terrors - might have been lost to history'. Kim Phuc concluded 43 years later: 'I realized that if I couldn't escape that picture, I wanted to go back to work with that picutre for peace. And that is my choice' (Newton and Patterson, 2015). Nick Ut's 'Napalm Girl' was one of the most iconic, resonant and enduring images of the Vietnam War; it was also, as Kim Phuc's ambivalence demonstrates here, an equally forceful example of the child's powerlessness in front of the adult camera. As a war photograph Nick Ut's image is exemplary; alongside news footage of U.S. soldiers in body bags, it brought 'home' - into living rooms, onto kitchen tables - the brutality of war. Ut (just 15 years old himself in 1972) did not just take the photograph, he also accepted some responsibility for it, taking Kim Phuc to hospital to receive treatment for her burns. And yet, Ut's photo ultimately also reverberates with the child's vulnerability and lack of control over her or his image and how it might be used. The photograph but not the child is in this instance performative.

In Documentary: Witness and Self-revelation, John Ellis frames his discussion of documentary performance through engaging with sociologist Erving Goffman's ideas of the presentation of the self in everyday life. In the Preface to The Presentation of the Self in Everyday Life, Goffman asserts that in his 'report', which borrows from theatre and dramaturgy: 
I shall consider the way in which the individual in ordinary work situations presents himself and his activities to others, the ways in which he guides and controls the impression they form of him, and the kinds of things he may and may not do while sustaining his performance before them (1959: xi).

Goffman immediately recognises the shortcomings of his equation between the performances of 'real life' and the 'make-believe' of the theatre. In the latter scenario, Goffman observes, there are three parties: the player, the character and the audience; conversely in 'real life' 'the three parties are compressed into two' as 'the part one individual plays is tailored to the parts played by the others present' (xi). A little later, Goffman subdivides the individual's social performance into 'the expression that he gives and the expression that he gives off (Goffman 1959: 2), the use of verbal and other symbols in a variety of social situations that can range from the subconscious to the deceitful. Goffman offers a spectrum of social performances, though one that is underpinned by an awareness of self-presentation that only comes with a quintessentially adult awareness of the expediency of masquerade, to borrow Joan Rivière's term. Children, like adults, can perform and strike a pose; even the children in San Pietro who have never seen a movie camera before, acquire a self-consciousness by virtue of being looked at. However, what is lacking when it comes to children's expressiveness is a fuller understanding of themselves as social as well as individual constructs. Unlike adults, their faces do not automatically represent 'the expression(s) of biography and experience' (Ellis 2012: 50. My italics). Children necessarily complicate Ellis's understanding of the classic documentary situation in which 'there are moments when every person can choose to be sincere' (51); children, especially those in traumatic situations, are not necessarily conscious of the performative choices they could make. Having said this, both Capturing the Friedmans and Tarnation exemplify the notion that the child can understand (only too well) the implications of the camera's gaze, whereas, conversely, my first two case studies 
'Seven Up!' and Être et avoir, offer more conventional examples of childhood alacrity and naïvety.

Although it has since become the first in a longitudinal documentary series, 'Seven Up!' - one of the most instantly recognisable child-centred documentaries - was originally conceived as a one-off film for Granada Television's current affairs World in Action strand. Paul Almond, a Canadian, and World in Action's first series editor Tim Hewat, an Australian, were fascinated and horrified by the rigidity of the British class system and set about making a documentary through which to explore it. The starting premise for 'Seven Up!' was Jesuit founder Francis Xavier's maxim 'Give me a child until he is seven, and I will give you the man'. Through interviewing and observing sevenyear-old children, Almond and Hewat wanted to test the theory that it is a child's social background that determines his/her adult future and their social positioning, so their two researchers, Michael Apted and Gordon McDougall spent three weeks finding 20 children from across the social spectrum. 'Seven Up!' is heavily didactic, counterbalancing Douglas Keay's heavy 'Voice of God'4 narration with interviews with the children and footage of them being brought together for one day in London when they go to the zoo, play in an adventure playground and have a party.

The interactive, ${ }^{5}$ interview-based form 'Seven Up!' adopts formalises the relationship between the adults behind the camera and the children in front of it, unlike the less intrusive observational style adopted by either San Pietro or Être et avoir. The question and answer format leads to the clear demarcation of adult and child domains and roles and imposes onto the children's responses an adult perspective (reinforced by the fact that consent for the children's participation in the documentary was granted not by them, but by their parents or guardians). Much of the narration and many of the prompting questions relate to social concerns (such as: what are the children's views of racial difference; what do they think of children from different social backgrounds to 
their own) and to the issue of growing up (which schools and universities the children think they will attend; what they want to become). These concerns, it could be argued, are intrinsically adult, although many of the 7-year-olds already appear to have a sense of where they are headed as adults. The trio of prep school boys interviewed together on a sofa (John, Andrew and Charles), for example, cheerily rattle off the list of independent schools they will attend prior to going up to either Cambridge or Oxford while they fidget about, talk over each other and fiddle with their regulation knee-high woollen socks. At the other end of 'Seven Up!'s social spectrum, a wary Paul asks, 'What does university mean?', Sue says she is 'going to work in Woolworth's' and Tony almost sings with excitement when he reveals that he wants to become a jockey when he grows up.

Although the only faces featured are those of the children and their classmates, they are fitted into an adult-determined documentary. However likeable the grinning Neil is when explaining that he wants to 'be an astronaut, but if I can't be an astronaut, I think I'll be a coach driver' or however socially aware Jackie shows herself to be, despite being framed by the film as one of the less privileged East End girls, when she says that, if she had $f_{2} .00$, she would help the poor, 'because the poor, if you don't help them they'd sort of die', 'Seven Up!' is prescriptive and the children's performances defined by the documentary's ideological parameters. It is the adult voices - Keay's avuncular narration or the occasional questions from behind the camera - that typically presages a sequence and thereby dictate what ensues. 'Seven Up!' is obsessed with class and although it sets out to subject the British class system to scrutiny, it comes nowhere near subverting it, but rather confirms its resilience and rigidity, through its script, its questions and the hierarchical filmmaking techniques it adopts, notably the interview. The film ends with Keay suggesting it has given a glimpse of Britain's future, but what 'Seven Up!' rarely gives a glimpse into is the children in situations not directed by adults. The moments when the child subjects do arguably manage to shuffle off the coil of the film's didactic 
format are when they are captured doing other things besides being interviewed for

'Seven Up!' - jostling in the picture queue on Saturday morning, playing in the

playground or visiting London Zoo. Despite the persistence of the potentially oppressive 'voice of God', these sequences are permitted to live and breathe in ways the interviews only sporadically do. The energetic hand-held camera mucking in with the children queuing for 'the flicks', observing their expectant faces and their lively exchanges, is fleetingly reminiscent of Truffaut's puppet show, and how that documentary-esque $\underline{\text { sequence momentarily leaves behind the fiction film that surrounds it. It is a great pity }}$ that even here Keay feels the need to tell us what to think.

For all its fascination as a longitudinal study (and here I have consciously talked only about the first, stand-alone documentary), 'Seven Up!' does not grant its 7-year-old subjects much freedom to exist beyond the social archetypes its script requires them to conform to, so the children's performances are circumscribed and the interviews seldom elicit spontaneous responses. In the concluding playground sequence, for instance, as the children interact with each other, the narration draws our attention to the fact that the boys from the children's home are building a house. As Symon rather half-heartedly takes a pickaxe to a mound of hard earth, the sequence's contrivances seem to seep out, and one cannot help but wonder if these children were directed to build a house. The children in 'Seven Up!' are representative figures as well as individuals; their social role as important as their personal performances. In Taking the Long View: A Study of Longitudinal Documentary Richard Kilborn observes that:

One of the several consequences of the longevity of long docs is that viewers are, in many cases, able to follow subjects whom they first encounter as children through to the phase in their lives where they are bringing up children of their own (Kilborn 2010: 89).

From a performative perspective, what occurs as the series goes along in terms of the cumulative relationships between the children and the adults they become is that, 
whereas in 'Seven Up!', the adult point of view was imposed onto or dictated the child's, later on in the series viewers are repeatedly invited to see the child in every adult (a process aided by the editing in of the childhood footage into each set of adult interviews), so that, in a reversal of convention, the child defines the adult. This inverted dynamic is most keenly felt in the case of Neil, whose appearances at seven are the most classically engaging and all-defining, and who later becomes obtrusively circumscribed by his psychological and nervous collapse, evident from the age of 21. Through the painful later interviews, our primary impulse whilst viewing them is probably to want to recall the happy child who grimaces at the thought of 'coloured people' because the term makes 'you think of a purple person with red eyes and yellow feet'. The adult Neil has, overtly at least, lost that twinkly vitality, as he sits in front of dirty net curtains in his London squat at 21 , or admits at 28 , as he walks along the side of a breathtakingly beautiful loch in the Western Highlands of Scotland, that he's known locally 'as an $\underline{\text { eccentric', or becomes painfully_articulate at } 35 \text { in Shetland when revealing how viewers }}$ 'flooded me with letters and thought I could solve their problems'. Neil seemed to suppress his childish unselfconsciousness earlier than the other Seven Uppers (maybe with the exception of Suzy in the aftermath of her parents' divorce), but our awareness of Neil's painful loss of innocence cannot be the only explanation for our powerful responses to the later interviews (and the collectivity of the Seven Up series viewing experience over the decades is exemplified by the regular outpouring of emotion over Neil). It is also that Neil articulates what it is to be a child with greater acuity than many of his peers. Childhood, Neil's passage through life suggests, offers no preparation for or no protection against adulthood. He remains powerfully, movingly eloquent about both life and himself; his alienation from society as an adult being felt all the more keenly as, with each episode, Michael Apted reminds us how his present anxious idiosyncrasies are at odds with his appealing childish cheeriness. We probably look for clues in the ultra 
serious, chess-playing boy of 14 for what was to come, but by and large the clips from the earlier 'Seven Up!' provide seductive and nostalgic relief from the bitter realities from 21 onwards.

The generational narrative dynamics of Être et avoir are not the same as those of 'Seven Up!' in that the differences between childhood and adulthood are acted out on the screen as opposed to from one side of the camera to the other. Philibert's documentary follows a tiny rural French primary school in the Puy-de-Dôme region (comprising a single class for children of all ages through to second school) through the seasons and from the start to the end of a scholastic year. The focal point of the interaction between children and adults is the pupils' engagement with their teacher, Georges Lopez, and as Phil Powrie observes, 'we rarely see the families of the children, as if the school, which has children of all ages in a single class, provides a surrogate family closer to what Roudinesco calls the "tribe" than the bourgeois family of modern times' (Powrie, 2005: 345). Lopez, who is in virtually every sequence, is, for his pupils, in omnipresent loco parentis, functioning as their teacher, mentor, counsellor and nanny. He is an idealised surrogate father, notably effective with Natalie, one of his older pupils about to depart for middle school. Natalie is an elective virtual mute; one especially emotive sequence occurs towards the end of the film as Lopez questions her about her extreme taciturnity and talks to her about the potential difficulties of transferring schools. The primary school classroom in Être et avoir is a cocoon in which Lopez protects children not yet ready yet for the adult world.

Philibert's documentary is refreshingly old-fashioned. Its cinema verité languidness makes it appear blissfully unaware of docusoaps, reality television and all the other recent transmutations of the observational documentary mode that had evolved around it; the film's depiction of children, school and life in rural France likewise disavows Goffman's notions of presentations of self or Butler's of performativity. Shari Kizirian considers the 
timing of Philibert's seventh feature-length documentary as historically important - that Etre et avoir premiered at Cannes in May 2002, some nine months after the attacks on the World Trade Centre, 11 September 2001 and less than a year before the US's 'misdirected fury was unleashed on the Iraqis' (Kizirian, 2011). Against this turbulent political backdrop Philibert 'provided a brief respite of calm', shutting out the brutalities of the world around it (in a manner the much earlier San Pietro had not). The film's soft, anachronistic style informs it throughout, and permits Philibert to capture the privileged adult/child exchanges, such as the oft-cited dialogue between Lopez and Jo-Jo as the teacher tries to get his cute but stubborn pupil to wash his paint-encrusted hands. The trusting, loving looks between teacher and pupil only become available to a director and crew who have filmed with their subjects for almost 600 hours. Philibert's imagining of childhood as more or less idyllic offers contrast and respite to the brutality of earlier images of children being liberated from the concentration camps, for example, or Kim Phuc running naked down a South Vietnamese road, which Judith Butler argued 'disrupted the visual field and the entire sense of public identity that was built upon that field' (Butler 2006: 150).

Philibert's style is in keeping with the film's delight in Lopez's old-fashioned education methods; the non-intrusive observational mode adopted by Ê to corroborate the fact that pupils, especially the younger ones, are only just beginning to learn the language that, in Lacan's (or Goffman's) terms, will mark them out as social entities equipped to engage with an adult-defined world. The children's relative innocence and the documentary's demarcated distinction between the domains of childhood and adulthood are emphasised in the sequence only a few minutes in during which Jo-Jo and some of the other smaller children are being taught to write through being asked to form the word 'maman'. Moments later, a group of smaller children again are mixing the ingredients for pancakes the older pupils will toss, making a dreadful mess 
in the process. The idyllic pre-adult 'innocence' of this school experience is emphasised by the fact that so much of what we see being learnt in Etre et avoir is being learnt for the first time. Conversely, the older children are overtly preoccupied at the prospect of having to leave this idyll behind. Natalie's trauma at her imminent separation from Lopez - the surrogate parent who understands and is sympathetic to her pathological silence or the pre-adolescent tensions between Olivier and Julien are framed negatively, in Etre et avoir as being part of growing up: the children's necessary but painful transition to middle school, adolescence and experience. There is here a sentimental idealisation of the innocence of childhood, but one that at the same time acknowledges the adult impulse to return to that pre-Fall state. The perpetual duality of Etre et avoir as an adult viewing experience (leaving us aware of our maturity at the same time as wanting to deny it) emerges in a sequence such as the one in which Jo-Jo and Marie struggle to photocopy some pages from a book. Jo-Jo teeters on a chair and discards the many miscopied reproductions, clumsily moving the oversize book around the glass in the vain hope of positioning it correctly. We adult would be able to help, but would most likely simply wish to sit back and relish the spectacle of him getting it wrong and learning. As he walks away (having been unceremoniously shoved off the chair by Marie who wants to try her luck at copying) Jo-Jo glances briefly into the camera, peripherally or fleetingly aware of its (adult) attentions, but not (yet) destabilised by it.

Two documentaries in which the distinction between child and adult perspectives is blurred if not altogether erased are Capturing the Friedmans and Tarnation, both of which use a significant amount of childhood home movie material juxtaposed with footage of the far more recent past, and both of which are also structured around personal testimony and memory. Through the course of both films, one comes, as a spectator, to appreciate that personal testimony and 'truth' are neither consistently, nor reliably related. ${ }^{6}$ This is especially the case with Capturing the Friedmans, a documentary that opens 
to the strains of the 1963 pop hit 'Act Naturally', a superficially at least, facile song that equates the ability to act naturally with becoming a big movie star. Used here to faux naïve effect, the track forms an apposite backdrop to the documentary's commentary on the Friedmans' own ostensible naivety (in inviting_director Andrew Jarecki in to film them) and their abilities to 'act naturally' for the home movie camera - even after Arnold's trial has begun. ${ }^{7}$ As the opening to a film about charges of paedophilia (brought against father and son Arnold and Jesse Friedman) the brazen glibness of this opening is unsettling, especially set against the home movie archive. Home movie footage frequently appears in films dealing with familial trauma, for example in Alina Marazzi's Un'ora sola ti vorrei (2002) in which she knits together home movies to try to piece together her dead mother's life, Sarah Polley's Stories We Tell (2012), or Margot Nash's The Silences (2015). Found footage often contains evidence that contradicts the memories or stated experiences of those captured on camera. Although it subsequently emerged that Jarecki and producer Mark Smerling actively appealed to get Jesse's conviction quashed, the filmmakers' interpretation of the Friedmans' home movie footage remains ambiguous, leading to film critic Xan Brooks criticising Capturing the Friedmans for 'its teasing lack of judgement' (Brooks 2004:).

As details of the case emerge, as the family falls apart and finally as Arnold dies in prison, the discordance between reality and superficially happy memories (the joshing around in the home movies) becomes irreversible, and it becomes traumatic to look at images of the Friedman children playing against the backdrop of this story of child abuse, especially as so many of the home movie sequences are prefaced by or juxtaposed with the words of mother Elaine Friedman, the one family member who, from the outset, believes her husband (at least) to be guilty. There are two layers of home movie in Capturing the Friedmans: the original (putatively more 'authentic') childhood footage, and the material David Friedman films around the time of his father's and brother's arrest, 
which contrasts with and problematises the residual 'innocence' of the earlier footage. The juxtaposition of the two means that even the childhood images have lost their innocence and no longer conforms to the ideal of "conscripted "togetherness" the family home movie putatively represents (Orgeron and Orgeron, 2007: 49). When Jesse's lawyer, Peter Panaro, recollects, for example, that his client told him he had been abused by Arnold as a child, this revelation is juxtaposed with pictures of Jesse as a child. Elaine repeatedly asserts that the Friedmans were 'a family' (with all the suggestions of "conscripted "togetherness" that term implies) and home movie material to support her case - birthdays, holidays and the like - is inserted, only to be disavowed or contradicted by events and by Elaine herself. The apparent 'truth' in this case does not reside in these images of happy children smiling at and playing up for the camera ${ }_{2}$ but in the shocking collision between these and the allegations of paedophilia. All four documentaries discussed in this article enact the dialogue between adult camera and child subject, alongside the more complex concomitant dialogue between childhood and adulthood. But whereas 'Seven Up!' and Être et avoir clearly demarcate the generational domains, Capturing the Friedmans and Tarnation (which I talk about in more detail below) are films about huge and tragic subjects (allegations of child abuse and a mother's schizophrenia), which instead share and express a sense of the loss of that distinction between the generations. The separation and distance between generations compels us as viewers to reconsider the status of the performances for and in front of the adult camera and to fret about the differences between the potential fakery of the performances of excessive 'innocence', 'naturalness' and 'happiness' rendered in Capturing the Friedmans and the apparently straightforward naivety of the childish performances in Etre et avoir or Seven Up. Although Capturing the Friedmans still touches on a collective understanding of the home movie as a vehicle for 'capturing' the family at its most 'authentic', it nevertheless also brings in more ambiguous notions of the dysfunctional family playing at being a 
family, in which context the home movie comes to represent the uncanny re-enactment of innocent domesticity as opposed to its embodiment. The ambivalent connotations of this relationship, like the lyrics of 'Act Naturally', suggest that 'they' (the adults) 'will make a big star out of me' if I (the child) 'act naturally' for their cameras.

Released the same year as Capturing the Friedmans and only a year after Etre et avoir, Jonathan Caouette's Tarnation offers a quite unambiguous image, morally speaking, of traumatic childhood. Elsewhere in Documentary: Witness and Self-revelation Ellis discusses 'slow film' and how shooting and editing have both 'undergone radical changes since the 1980s under the impact of successive forms of digital technology' (Ellis 2012: 84). Ellis is principally interested in the impact of these developments on working practices - that documentary filmmaking is now 'more accessible beyond the confines of the broadcast and cinema industries' and that 'it has become easier to edit, and easier to construct complex combinations of sounds and images' (84). He goes on to cite Geoff King on the increase in the rapidity of particularly Hollywood editing and shot length, but Ellis' distinction between slow and fast film accurately reflects the differences between $\hat{E}$ tre et avoir, an ostentatiously 'slow' documentary, and Tarnation, with its use of short shots, split screens and complex soundtrack, an at times parodically 'fast' one.

Caouette's working methods and techniques have been well documented in virtually every article written about the film: that he shot the adult portions of Tarnation on a Sony Handycam and the childhood sections on Hi-8; that he edited over 160 hours of footage using free iMovie software; that it cost a mere $\$ 218.32$ to make, excluding distribution costs. Caouette describes Tarnation as 'an amalgam of everything: excerpts from my own CD collection; grabbing pieces from VHS and going to my Hi-8 camera. Then uploading that into the movie' (Hegarty 2007: 28). It borrows its style from the traditions of non-narrative avant-garde film and music video, despite the imposition of a very clear narrative arc, namely the story to date of Caouette's turbulent life. Tarnation is, 
as Caouette identifies, a film he was predestined to make. He had been 'compiling everything, grabbing everything starting at the age of ten and half or eleven', leading to the 'odd' sense that 'I've been inadvertently making this film all my life' (Hegarty 2007: 28), a filmed life that continues into Walk Away Renee, the follow up feature which premiered at Cannes 2011. ${ }^{9}$

Recalling Susan Sontag's assertion that 'to live is to be photographed' and that to be photographed or 'to pose' offers the subject 'deep satisfaction', Tarnation moves us as spectators precisely because it suggests that, throughout Caouette's life (not just as an adolescent or adult), living and posing have been interchangeable facets of the same experience, which for a child (as he is in the earliest home movie footage extracts) is not only atypical but potentially traumatic. The definition of 'tarnation' is the act of damning or the condition of being damned; ${ }^{10}$ instead of signalling a distinction between childhood and adulthood, the documentary Tarnation suggests that they are points on the same continuum - that childhood is 'damned' by segueing all too smoothly into adulthood. This psychological and intellectual premise is, in turn, emphasised by the film's frenetic visual style and, specifically, Caouette's rapport with and use of his camera. Unlike the Friedman family for whom filming was a communal, familial activity, for Jonathan Caouette it is solitary and solipsistic, and the camera's gaze is ambivalently voyeuristic: it intrudes on and makes us uncomfortable viewers of the mental illness of Jonathan's mother Renee, his grandmother Rosemary and his grandfather Adolph; it also captures the equally traumatic spectacle of Jonathan's exhibitionist performances into it.

The most affecting and troubling of these is Caouette aged 11 filming himself, using his tripod-mounted camera in the hallway, as a made up character Hilary Chapman, an abused wife who, testifying in court, explains why she murdered her violent husband. Coming quarter of an hour into Tarnation, this is the documentary's first extended sequence. In close-up and speaking directly into the static camera 'Hilary' gives a painful, 
agitated account of her marriage to 'Jimmy', her 'little baby Caroline' and the repeated acts of domestic violence that culminated in 'Jimmy' pointing a gun to her head while shouting 'I'll kill you bitch, I'll kill you', before 'Hilary' 'blew his ass away'. The image is of imperfect quality, but the sickly tungsten yellow hue is morbidly appropriate, while the close-up image framed by the fixed camera lends the sequence claustrophobic intensity. This image of an eleven-year-old boy giving a moving, hysterical rendition of an abused wife is, to borrow from Sontag, atrocious and haunting. Caouette, the sequence suggests, both knows and does not fully comprehend the implications of his performance and, as a result, explodes securely held beliefs about documentary's inherent performativity: the surety of Ellis' idea that 'Face is, in many ways, the expression of biography and experience' (Ellis 2012: 50); Thomas Waugh's notion of 'the right to play oneself (Waugh 2011: xv); or my own borrowings from Judith Butler in formulating my definition of all documentary as performative. In one interview Caouette gives this elliptical account of Hilary:

It wasn't a character that I developed prior to [filming]. It was actually inspired by two compelling things that I saw on television that day, and I just turned the camera on and just kind of went to town ... acting was the only out that I had. Definitely looking back, there was in Hilary an emulation of my mother ... It was a very abusive marriage she went through ... Some of the story, specifically the gun held up to her head, being kicked in the stomach, all that stuff my mom has gone through, that she told me about, I believe. (Hegarty 2007: 21)

Jonathan Caouette's multiple performances and the fictional characters he constructs, especially within the context of his explosively fragmented documentary, enact the early loss and destruction of childish innocence. Tarnation is, ostensibly at least, a documentary about adult lives from a child's point of view; within this framework it presents the generational world turned upside down: its adults are so needy, so unstable that certainty, solidity and awareness reside more with the child - a child, though, who has experienced neither the normative state of childhood 'innocence' nor the equally 
normative transition from childhood to adulthood. However, inasmuch as 'in the ranking of suffering, children become substitutable and no longer recognisable as individual humans' (Butler 2005: 29), Caouette's uprooting and deeply unsettling 'performances of self (and multiple others), become representative of childhood suffering and neglect more pervasively.

Children's performances in documentaries problematize so many received ideas about documentary and how nonfictional images function. They are also full of contradictions: whereas for Jonathan Caouette 'to live' is 'to be photographed', the children in San Pietro, 'Seven Up!' and Etre et avoir have not yet learnt the rules of that particular game. And although the whole film is concerned with the mutuality of photography and living, neither have the sons in Capturing the Friedmans. Life, like documentary, is inherently performative for adults, but such an assumption is necessarily more contentious when applied to children, for performativity implies social and selfawareness, which are often, when it comes to children, still forming. Children's 'performances of self are typically either representative, as Butler argues (that is, they are placed in the position, as the children are in 'Seven Up!', of standing for, representing a social group) or, within the adult parameters of documentary film, mediated through adult eyes. 'Be yourself is an oddly impossible instruction to an adult, but it is a more realisable proposition to a child because, as we see in the photocopier scene in Être et avoir, there is a greater chance that for children, what they are experiencing in their here and now, is of more interest than the fact that they are being filmed. Although not all children are equally innocent, the intellectual and psychological complexities of the gaze and the camera's objectifying potential have not, by most children, been fully negotiated. Through discussing contrasting examples of the child in documentary I have sought to explore how they are all, in diverse ways, expressive of generational tensions between adult and child, between the adult looking at children and children returning that look. 
When, in a documentary such as Tarnation (in which its autobiographical status also serves to unhinge the notion of there being a definite separation between adult and childhood experiences), these generational differences are subverted, so childishness becomes engulfed by the implied guile and disingenuousness of performances that we are aware have been constructed specifically for the camera. Conversely, in documentaries such as Etre et avoir, the children are fascinating because they are, firstly, so different from us, and secondly so ostensibly unaware, in most cases, of the perils of growing up. One of the most frequently viewed and cited sequences from Spellbound is Harry misspelling 'banns'. Harry squirms and grimaces as he circles round the possibilities of this short but tricky word, untroubled - or so it seems - of the 'performance of self' he is giving. But what is the pleasure in watching this? It is not seeing a child fail, but rather having him confirm his difference and his, as yet, indifference either to Mulvey's notion of 'to-belooked-at-ness' or to the perils and powers of documentary performance._On the one hand it could be argued that children are at their most beguiling when they appear to be without guile, when, like Scout and Jem in To Kill a Mockingbird, they have not learnt to fear Boo Radley or when they are still able to exist in the moment, responsive and unpremeditated, like Philibert's Jo-Jo. On the other, though, Jonathan Caouette's multiple performances of self are equally intriguing, as are the hard-knock child's streetsavviness in Les 400 Coups or, much more recently, in Jonas Carpignano's dramadocumentary essay film, A Ciambra (2017), in which the 14-year-old Romani boy, Pio, is proud to assert 'I am already a man' or The Florida Project (Sean Baker, 2017), in which the worldly-wise six-year-old Moonnee insists she 'can always tell when an adult is about to cry'. In this essay, I have intentionally compared documentaries from the preSmartphone era, when cameras were not ubiquitous, and when the average Western child did not yet spend several hours a day looking at or into a screen, frequently taking photographs of themselves to post to friends on social media. Cameras are now 
omnipresent, and children outperform adults when it comes to how to use them.

Although we might still want to believe in the young child's 'innocence', ignorance of the camera or of the power dynamics of voyeurism are no longer corollaries of such 'innocence'.

Note: I would like to record my thanks to the useful and thoughtful comments of my anonymous readers.

\section{Stella Bruzzi}

\section{Stella Bruzzi is Professor of Film and Executive Dean of the Faculty of Arts} and Humanities at University College London.

\footnotetext{
${ }^{1}$ Thanks to one of my anonymous readers for this point.

${ }^{2}$ Cf. John Corner The Art of Record: A Critical Introduction to Documentary, Manchester: Manchester University Press, 1996.

${ }^{3}$ For example John Berger's description of gendered difference in $W$ ays of Seeing: 'One might simplify this by saying: men act and women appear. Men look at women. Women watch themselves being looked at. This determines not only most relations between men and women but also the relation of women to themselves. The surveyor of woman in herself is male: the surveyed female. Thus she turns herself into an object -- and most particularly an object of vision: a sight'. (John Berger Ways of Seeing, 1972: 45). And also Laura Mulvey 'Visual Pleasure and Narrative Cinema', Screen, 16:3, October 1975.

${ }^{4}$ 'Voice of God' narration is generally understood to be authoritative, male voiceovers, such as Laurence Olivier's in The World at $W$ ar. For a full discussion of narration in nonfiction film, see Chapter 2 (pp. 47-72) of New Documentary (Bruzzi 2006).

${ }^{5}$ For a full discussion of the 'interactive mode', see Bill Nichols Representing Reality, Bloomington and Indianapolis: Indiana University Press pp. 44-56.

${ }^{6}$ Cf. my discussion of Capturing the Friedmans is New Documentary ( ${ }^{\text {nd }}$ edition, Routledge 2006, 238-45.

${ }^{7}$ Lyrics quoted in Capturing the Friedmans include: 'They're gonna put me in the movies, They're gonna make a big star out of me'.

${ }^{8}$ For example, Jarecki and Smerling 'spent the years since the documentary's release traveling the world at their expense to interview some of the 14 former students whose testimony contributed to Jesse Friedman's conviction' (Levy 2012).
} 
${ }^{9}$ However, the two features fulfil markedly different personal functions for their director: Tarnation 'was made with a sense of urgency, and there was a heavy sense of catharsis connected to it' while conversely Walk Away Renee was made 'a lot more out of happenstance and circumstance ... it was more about the idea that I had a lot of B-roll from Tarnation just residing on external hard drives, and I had the need to do something with it' (Osenlund).

${ }^{10}$ Cf. http://www.thefreedictionary.com/tarnation, which also indicates that the term is specific to New England and the Southern US.

Bibliography

Apted, Michael (2007) Interview with the author.

Brooks, Xan (2004) 'Family Viewing' (Review of Capturing the Friedmans), Sight and Sound, 14:4 (April): 40-1.

Bruzzi, Stella (2006) New Documentary, London and New York: Routledge

- (2007) Seven Up, London: British Film Institute

Butler, Judith (1990) GenderTrouble: Feminism and the Subversion of Identity, London and New York: Routledge

-(2006) Giving an Account of Oneself, Fordham University Press

Cousins, Mark (2014) 'Age of Innocence: Childhood on Film', Sight and Sound, April.

(http://www.bfi.org.uk/news-opinion/sight-sound-magazine/features/age-innocencechildhood-film, accessed 21 April 2018).

Ellis, John (2012) Documentary: Witness and Self-revelation, London and New York:

Routledge

Goffman, Erving (1959) The Presentation of Self in Everyday Life, New York: Doubleday Hegarty, Laurence (2007) 'An Interview with Jonathan Caouette', Projections, 1:2, Winter, $17-36$.

Kilborn, Richard (2010) Taking the Long View: A Study of Longitudinal Documentary, Manchester University Press

Kizirian, Shail (2011) 'Être et avoir: The Medium and the Moment', Senses of Cinema, October 05.

Landy, Marcia (2000) Italian Film, Cambridge: Cambridge University Press.

Lebeau, Vicky (2008) Childhood and Cinema, London and Chicago: Reaktion

Newton, Paula and Patterson, Thom (2015) 'The girl in the picture: Kim Phuc's journey

from war to forgiveness', http://edition.cnn.com/2015/06/22/world/kim-phuc-whereis-she-now/index.html. Accessed 11 June 2017.

Levy, Tracey (2012) 'Exonerating the Friedmans', Tablet.

http://www.tabletmag.com/jewish-arts-and-culture/117317/exonerating-the-friedmans. Accessed 11 June 2017.

Orgeron, Marsha and Orgeron, Devin (2007) 'Familial Pursuits, Editorial Acts:

Documentaries after the Age of Home Video', The Velvet Light Trap, 60: 47-53.

Osenlund, Kurt (2012) 'Interview: Jonathan Caouette', 20 July,

www.slantmagazine.com/film/feature/interview-jonathan-caouette/319

Powrie, Phil (2005) 'Unfamilar places: "heterospection" and recent French films on

children', Screen 46 (3); 341-352.

Rose, Jacqueline (1984) The Case of Peter Pan, or the Impossibility of Children's Fiction, Philadelphia: University of Pennsylvania Press.

Sontag, Susan Regarding the Pain of Others, London: Penguin, 2003.

- (2004) 'Regarding the Torture of Others', New York Times Magazine, May 23, 24-29;

49 . 
Waugh, Thomas (2011) The Right to Play Oneself: Looking Back on Documentary Film, Minneapolis and London: University of Minnesota Press. 
Stella Bruzzi is Professor of Film and Dean of Arts and Humanities at UCL. Prior to that she was at the University of Warwick, where she was Chair of the Arts Faculty and Head of the Department of Film and Television Studies. Her main research areas are: documentary and representations of reality; costume and fashion; masculinity on film. She is currently writing Approximation: Documentary, History and the Staging of Reality (Routledge), which began life as a Leverhulme Major Research Fellowship. She was made a Fellow of the British Academy in 2013. 